\title{
Freedom as a Dialectical Expression
} of Rationality

\author{
CAROL HUNTS \\ University of Kansas
}

The concept of what we may noncommittally call forward movement has an all-pervasive significance in Hegel's philosophy. Hegelian forward movenent is of a particular kind; it is dialectical. Whether our realm of discourse is the individual, the community, the State, or World Spirit, change must be perceived as a dialectical forward-moving, and the subject of discourse at any particular time must be considered in its relationship to the whole, with regard to its position and significance within that whole. Dialectical change, newness as a manifestation of freedom, and in particular the freedom of the natural individual to initiate developmental changes in his own iffe, is that with which I will be concerned.

In "Mental Events", Donald Davidson describes two related distinctions which appear at first to be contradictions; (1) that between autionomy or freedom and causal determinism and. (2) that between the anomaly of mental events and the determinate nature of physical laws. In the first part of this paper I will draw on Davidson's formulation of the former issue as derivative of his resolution of the latter in order to illustrate how Hegel's notions of freedom and rationality as dialectical, as historically evolving, enable him to exhibit these distinctions in an entirely different light.

In "Ereedom and Constraint by Norms", Robert Brandom develops and extends [1] the Hegelian notion of freedom in such a way as to stress the element of novelty, as which freedom is freedom to do and express new things. In the second part of this paper, I will further analyze Hegel's notion of freedom as dialectical, based on some of Brandom's insights, in order to 
emphasize the role which freedom qua expressive has in historical development and continuity.

Events, says Davidson, are either mental or physical only by description. In the sense that all events are described as physical, they can be given purely pliysical explanations, or their explanations can be hypothesized within the realm of a purely physical theory. Mental events are recognizably different from physical events. For one thing, not all events are mental, while all events are physical. Eor another thing, allegiance to the 'proper sort of evidence' in the explanation of events in the mental realm is an allegiance of an entirely different sort than that which physical explanation requires. Evidence of a physical sort will be operative within the boundaries of a (pliysical) theory; it will both depend upon and substantiate that theory. Evidence gathered at any time may either constitute a demonstration of the consistency of the theory, call for revision of the theory within the limits of its major claims, or require an overthrow of the theory in favor of another, better theory. |2|

Within the mental realm, events constitute evidence for the consistency of a theory, the need for its revision, or the necessity of its overhaul in an entirely different way. To interpret mental events is to recognize them as constituting a pattern and to comprehend that their description is conferred upon them by their place in that pattern. Mental events are unique in that they represent a continually changing and evolving realm. If we are to have a theory about a person's thoughts, beliefs, etc. , we must accept that it will continualiy have to be revised. The theory itself must evolve because the person is not static but is changing according to some patterned flow. [3]

How can we characterize this pattern as which mental events must be viewed? We must recognize, claims Davidson, the holism of the mental realm, the fact that every belief has been conditioned by previous psychological states (beliefs, desires, hopes, etc.). As such, our every interpretation relies on the attribution of rationality to the person whose mental states we seek to understand. To attribute some degree of comsistency and colherence to a person with regard to his thoughts and beliefs is just to treat him as a person, to say that in the sense that he is a being 
whose thoughts are evolving, he is rational, purposeful, and free from physical laws. 'To view the mental realm as anomalous, concludes Davidson, is a necessary condition for interpreting the actions and deeds of persons as autonomous. [4]

The characterization of an event as mental or physical only by description is at least superficially applicable to Hegelian terminology. Contrasts in Hegelian philosophy become poles, having different characters only contextually, depending on the combination of light and shadows in which they are seen. Even in their synthesis they have different aspects or sides.

However, Hegel's account of the person and his mental and physical aspects differs fundamentally from Davidson's. Whereas for Davidson, all mental events can be understood as physical events, for Hegel the mental takes precedence and the physical must be subsumed. Davidson has asserted that physical events are noticeable, law-abiding, and primary, but Hegel wants to show that the physical or objective world relies totally on the mental. The pole of the mental is represented in many different ways in the Hegelian system: as subject, as inner realm, as will and thought. Each of these is substantiated or concretized in its opposite; the object, the outer realm, natural necessity. It is because Hegel conceived of the element of rationality as primary rather than derivative that he is able to depict relations in this way.

The mark of the primacy of the mental realm for Hegel is the rationality of the subject. He presumes that the individual as subject, as agent, is rational. It is this guality which gives sense to his existence and which enables him to be understood by others. The subject thereby lives a coherent existence in which his attitudes toward the world are ever-evolving and flowing in a pattern in which each is related both to what is to come and what has gone before. What Hegel further means by the rationality of the subject is that he is such that, as a thinking agent, he extends his rationality into the world. This can be understood again in the following way: The subject is rational because he is imbued through and through with reason, and by way of reason he sees his reflection in all things.

Reason. - . Is Substance, as well as Infinite Power; its own Infinite Material underlying all the natural and spiritual life which it originates, as also the Infinite Eorm- that which sets this material in motion. . It is the in- 
finite complex of things, their entire Essence and truth. [5]

Reason is apparent everywhere and governs everything. Thus, both the spiritual and natural worlds are within the domain of reason in every way. That the subject is rational, and that he investigates his rationality in the world is to say that as subject he is a manifestation of reason. He is a participant in the principles of reason in such a way that he seeks reason elsewhere and everywhere, not only in other subjects, but also in the natural or physical world. He seeks rationality then, in physical objects and events, and he finds it there.

To him who looks upon the world rationally, the world in its turn present a rational aspect. (6)

Hegel thus reverses the Davidsonian dependence between mental and physical events. While for Davidson, all events are physical, in the Hegelian system all events must ultimately be mental. It is the subject (his thoughts, beliefs, intentions, desires) to which everything has reference, the subject who is making his way in the world by locating in the world its own rational aspect. The subject, in giving reason to the world, finds reason in the world. Without the subject, there is mere externality, a disembodied, disorganized content waiting to be the content of some thought.

The content of something thought has the form of being; but this being is something mediated, something established through our activity.|7]

The allegiance of mental and physical explanations to their proper sort of evidence will, in the Hegelian system, be allegiance to the same sort of evidence; namely, that of reason penetrating both subject and object, making the physical world subject to rational comprehension by thought, and bringing the content of the physical world within the domain of the subject. A rational understanding is all-enveloping. Not only physical objects but physical laws, and therefore the whole realm of physical theory. which Davidson alternatively sees as undeniably separate and distinguishable, as being not rational but subject to causal determinacy, is veritably transformed in Hegel's system. The world and its constituents cohere as a 
rational system, capable of being recognized as rational by the subject.

To consider a thing rationally means not to bring reason to bear on the object from the outside and to tamper with it, but to find that the object is rational on its own account; here it is mind in its freedom, the culmination of self-conscious reason, which gives itself actuality and engenders itself as an existing world. $|8|$

To distinguish the role of the Hegelian concept of freedom we have but to draw on the notion of rationality a little bit further. The subject's awareness of his participation in a rational world is not a static awareness but an evolving one. For the individual to come to terms with his rationality is for him to become self-conscious. Througl a long period of seeking involving many changes, the individual progressively discovers that he can look upon both the pliysical world, and most importantly himself, as rational; his rational content is never once the same as it ever was before but its whole path is patterned and purposeful. The freedom of the subject is not freedom in the Davidsonian sense, from physical laws, but freedom to discover rationality in both himself as subject, and in the object. Freedom is thus the uncovering of rational laws for the subject to understand and to apply. Hegelian freedom is self-contained existence, since to be free is to be dependent on nothing but oneself, to be primary.

Thus the individual, as subject, is free, because he is rational. The element of reason which is manifest throughout existence is apparent to the sub$j \in c t$ who is free, who seeks his own rationality, who recognizes it, who finds it everywhere, and who brings all else that is rational within his domain. To be free moreover, is to perceive the world as working itself out in a free and rational way.

Ereedom is precisely that by which the subject achieves newness and reaches ever new boundaries. Ereedom is the basis of exploration and discovery within the world such that the same ground is never covered twice. Freedom is change, but more than this; it is evolution, progression, purposeful movement toward goals--i.e. the uncovering of rationality in the world and in the self. The basis of an individual's achievements is his ability to make free choices and to move continually in the direction of self-consciousness. The life of the individual can thus be seen as 
his own history, and the working out of this history, its very becoming and its reality, is the progress of the consciousness of freedom.

In sharp contrast with Davidson's portrayal of the schism between the mental and physical realms, the reduction of all events to physical events, the character of the mental as anomalous and the conclusion that anomaly is a necessary condition for autonoiny. Hegel presents a view in which forward movement is essential. The Davidsonian outlook appears static; we are in a very deep sense dependent on our physical theories and their evolution is oddly out of step with our progression as persons. We are dependent on the physical world and our theories about it, which we must take to be true and reliable at any given time. According to Hegel, the authority belongs to the subject who constitutes the world and takes it as it is related to himself at any given time. As subjects, we constitute the movements and the changes, initiating them in our freedom and our own self-development. As Charles Taylor puts it, here is the Hegelian resolution of the conflict between the radical freedom which man empliatically takes himself to possess, and an expressive fulness, which says that man as a whole, as mind and body, as complete, seeks to express his lumanity in the world.|9] Insofar as every individual seeks selfconsciousness, we have at another level the phenomenon of a people or culture. A community of subjects is a group of individuals acting in harmony with one another so as to express a particular character, to exhibit itself as a cultural individual in the context. of history, the larger life, so to speak, the life of the world.

\section{I I}

Freedom, claims Brandom, is an issue that is to be seen most clearly in the context of a community, for it is the way that the decisions, actions, etc. of the individual are interpreted by the community that leads to considerations as to whether that individual is free or not. The regulating factor in intracommunity appreciation is the norm. Norms governing utterances and social practices are implicit within the practice of the community; in other words, the norms of a community are to be taken as what the community responds to as a correct performance of a particular practice.[10] To be a member of a particular community it is necessary that an individual conform to the norms which are 
evident in the social practices of the community. We can treat anyone as a member of our comminity if and when we choose; insofar as we do, we treat him as a person, as one of us. When, however, we treat someone as if he were constrained instead by causes which fall outside of our realin of norms, we treat him as an object, and therefore as one alienated from us. The crux of Brandom's argument is that the distinction between treating something or someone as a member of our (or any) community or as not rests upon the judgment of the community and is therefore a distinction that is socially made. It is not an objective fact whether or not we should treat someone as a member of our community but a social matter, one upon which only the community as a whole is qualified to decide.|11|

The implications that this theory has for the interpretations of individuals as free within the community setting are as follows: We seek to understand the practices (utterances, actions, decisions) of various individuals not by causally explaining them but by translating them into the 'language' of our own practices, seeing how they fit into the web of what we accept as appropriate within the conmunity as a whole. To be coustrained by norms rather than causes, to be treated as a member of a community, is what it is to be free.

Our talk about human freedom is thus a rather misleading way of talking about the difference between the way in which we treat members of our own community, those who engage in social practices with us, and the attitude we adopt toward those things we manipulate causally.|12]

Brandom points out that Hegel saw as Kant's failure the non-grounding of norms and therefore of freedom in the content of those norms. Consequently. freedom was doomed to be merely formal and abstract. It was impossible then, for Kant to construct a science of society. It is precisely this point which Hegel attacks in order to make the concept of community possible.[13] In admiration of Kant's well-developed concept of morality, Hegel seeks its synthesis with the Aristotelean portrayal of ethical life.14l Hegel found the content of norms for which he souglit in their particular expressions in different cultures. (15) In effect, it is not just any norm to which an individual must adhere but adherence to the norms which will make him one of us, and each community is seen to be unique with regard to the norms it calls its own. 
The community is autonomous by virtue of its having, holding, and applying a particular set of norms. Individuals are free by way of the community. because they participate in the normative structure of the community and consider themselves socially embedded rather than constrained by causal laws. But the norms of a community must not be thought of as static. The community will appreciate and absorb change which appears in the form of freedon expressing itself over and above the communal norms. Certain unique practices of an individual or group will not be considered abnormal or unusual but will follow immediately or freely from the tendency toward newmess and progressive and purposeful change. Freedom is thus the capability to induce normative change in the community, the capacity to introduce novel practices. [16]

It is by virtue of participating in a certain set of social practices that an individual acquires the ability both to produce novel practices and to understand the novel behavior of others. Constraint by a set of norms is in fact a necessary condition for novelty, or for enlargement upon what is already accepted by the conmunity. [17]

The capacity of the individual for novel behavior must be maintained or exercised in order that both the individual and the community may continually evolve. Both self and social unit are thus cultivated and constantly enriched. This evolution is one that builds itself dialectically. Through every novel dimension in which the community is enlarged, new explorations are made possible. New desires, intentions, actions, and decisions on the part of individuals become acceptable to the community where they would previously have been inconceivable. Development in an historical sense is included in this framework. Again we can look to the basic principle of the inherent rationality of the individual within his community to see in what sense this is so.

Individuals may choose freely but not arbitrarily. They choose rationally and within the bounds of a particular set of norms which characterizes their community culturally. Historically, these norms represent an attempt on the part of the community to substantiate themselves as a moral whole. This attempt on the part of the conmunity and its members to characterize their system as complete, to claim that it "contains.

the possibility of a life of freedom under universal moral laws" $\mid 18]$, contradicts the actual existence of a set of prevalent norms, which delimit the boundaries of social practices, however indistinct these may be. 
This contradiction is that which dialectically propels each community forward to novel behavior wherein new norms are accepted and utilized, and new and higher level of rational life is achieved. (19)

Cultural development is thus a dialectical exhibition of the phenomenon of forward movement. Rationality is the element through which the community views and evaluates itself. Freedom is that which is capable of recognizing and utilizing rationality, so that both the individual and the community may become more conscious of themselves. Through freedom they seize their rationality more and more, seek to be at one with it and find that it is evident everywhere in the world around them. Freedom is also the ability to supersede, to be unique, creative, novel, to advance, progress, to move forward dialectically such that at no point in the life of an individual, a community, a people, or the history of the world is a moment repeated. This non-repetition however, is a patterned developing flow in which every moment is dependent both on what has gone before, and in a more limited sense, what is to come.

Hegel's own words from the Philosophy of Right will help sum up some of the ideas I have tried to convey:

- . (S)ince mind is implicitly and actually reason, and reason is explicit to itself in mind as knowledge, world history is the necessary development, out of the concept of mind's freedom alone, of the moments of reason and so of the self-consciousness and freedom of mind. This development is the interpretation and actualization of the universal mind.

The history of mind is its own act. Mind is only what it does, and its act is to make itself the object of its own consciousness. In history its act is to gain consciousness of itself as mind, to apprehend itself in its interpretation of itself to itself. This apprehension is its being and its principle, and the completion of apprehension at one stage is at the same time the rejection of that stage and its transition to a higher. To use abstract phraseology, the mind apprehending this apprehension anew, or in other words returning to itself again out of its rejection of this lower stage of apprehension, is the mind of the stage higher than that on which it stood in its earlier apprehension. [20\} 
The history of the mind (World Mind or World Spirit) is described by Hegelian forward movement as dialectical. The mind's history is the uncovering of rationality in all aspects of the world, most especially in the mind's coming to recognize its own rationality, its becoming conscious of itself. Freedom does not oppose natural necessity. but rather characterizes the movement of mind through life during which the physical world is to be understood at every turn as a manifestation of the rational in the objective realm, or as rationality concretized. Mind is free, mind is active, coming to be and evolving. It is continually new, continually changing, and overall, progressive. The development of mind thus constitutes history. To comprehend this forward moving in its implications at many levels is to grasp the purposive flux which is the foundation of the Hegelian system.

\section{NOTES}

'Robert Brandom, "Freedom and Constraint by Norms," American Philosophical Quarterly 16 (3). pp. 187-96. Brandom says, "Hegel envisaged. a higher form of positive freedom as self-expression and Bildung, enabled by but not reducible to constraint by communal norms. In the rest of this paper we consider such a notion, elaborated from Hegel's hints, but not intended as an exposition of the account presented by Hegel in his own original and ferocious idiom." p. 193.

"Donald Davidson, "Mental Events," in Experience and Theory, edited by Lawrence Foster and $J$. W. Swanson (Amherst: University of Massachusetts Press, 1970).

${ }^{3}$ Ibid.. pp. 96-97. This view is an interesting derivation of Davidson's construal of mental events as unique particulars rather than as kinds as psychological states.

"Ibid., p. 101.

sG. W. F. Hegel, The Philosophy of History, translated by $J$. Sibree (New York: Dover Publications, Inc.), p. 9.

Ibid. p. 11 . 
'G. W. E. Hegel, Hegel's Philosophy of Right. translated with notes by T.M. Knox (New York: Oxford University Press), p. 227.

Ibid. p. 35 .

'Charles Taylor, Hegel and Modern Society (New York: Cambridge University Press), pp. 1-6.

10 Brandom, p. 188.

"Ibid. , p. 189.

12 Ibid. , p. 192.

"Peter Laska, "Kant and Hegel on Practical Reason," in Hegel and the History of Philosophy; Proceedings of the 1972 Hegel Society of America Conference, edited by Joseph O'Malley, et. al. pp. 133. 137.

"Heimo E. M. Hofmeister, "Moral Autonomy in Kant and Hegel." in Hegel and the History of Philosophy; Proceedings of the 1972 Hegel Society of America Conference, edited by Joseph J. O'Malley, et. al.. p. 145 .

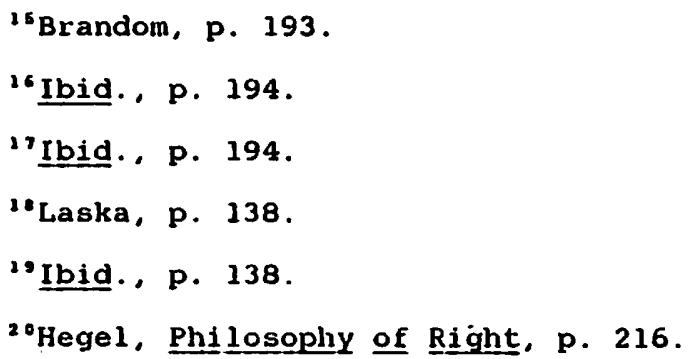

